\title{
(Poli)geny na język. Prolegomena do lingwistyki genetycznej ${ }^{1}$
}

\section{(Poly)genes for language. Prolegomena to genetic linguistics}

\author{
Adrian P. Krysiak \\ INSTYTUT JĘZYKOZNAWSTWA, UNIWERSYTET IM. ADAMA MICKIEWICZA \\ AL. NiEPODLEGŁOŚCI 4, 61-874 POZNAŃ \\ adrian_krysiak@wp.pl
}

Rodzicom dedykuję

\begin{abstract}
The paper is intended as an introduction to the field of genetic linguistics. The author tries to answer the question of what it means for a language to be a Darwinian adaptation and gives a few examples of "language genes". Some perspectives for further research have been indicated as well.
\end{abstract}

\section{Wprowadzenie}

$Z$ adaptacją (w sensie darwinowskim) mamy do czynienia wówczas, gdy istnieją geny danej cechy przystosowawczej. „Aby cecha mogła ewoluować $\mathrm{w}$ drodze doboru naturalnego konieczne jest występowanie $\mathrm{w}$ populacji genetycznej zmienności pod względem tej cechy”2, gdyż dobór genów lub ich alleli dokonuje się ze względu na ich efekty fenotypowe. Zeby więc uznać język za cechę przystosowawczą (np. Pinker, Bloom 1990; Gorzelańczyk, Nowakowski 1999), musimy wskazać na zróżnicowanie genetyczne w populacji pod względem tej cechy, co postaramy się uczynić.

Wysoki stopień złożoności zjawisk językowych oraz dane empiryczne wskazują, iż (i) istnieje wiele genów na tę cechę (poligeny), (ii) mutacja dowolnego genu na język spowoduje zmiany nie tylko

\footnotetext{
${ }^{1}$ Autor dziękuje Dr. Pawłowi Nowakowskiemu za uwagi dotyczące pierwszej wersji tekstu. Nie trzeba dodawać, że wszelkie błędy obciążają wyłącznie podpisanego. 2 Lewontin R.C. (1979) Sociobiology as an adaptationist program. Behavioral science 24, 5-14; cyt. za: Dawkins (2003).
} 
$\mathrm{w}$ języku, ale $\mathrm{i} \mathrm{w}$ innych, niezwiązanych $\mathrm{z}$ nim cechach fenotypowych (plejotropizm). Temu zagadnieniu również poświęcimy trochę miejsca.

\section{Kwestie terminologiczne i techniczne}

Jeśli zmiany strukturalne $\mathrm{w}$ danym genie pociągają za sobą zmiany $\mathrm{w}$ (fenotypowej) cesze $\mathrm{X}$, przy założeniu niezmienności pozostałych czynników, to powiemy, iż gen ten jest genem na cechę $X$ (na podstawie Dawkins 1996). Tak więc gen $G$ nazwiemy genem na język (na cechę $J$ ) wtedy, gdy zmiana strukturalna $\mathrm{w}$ genie $\mathrm{G}$ spowoduje zmianę $\mathrm{w}$ cesze $\mathrm{J}$, przy założeniu niezmienności pozostałych czynników. Nie proponujemy oczywiście żadnej wersji genetycznego determinizmu, gdyż mamy tu do czynienia z kooperacją całych zestawów genów (sieci regulatorowe genów - GRN), regulowanych w sposób skoordynowany w komórkach i tkankach, z wpływami środowiskowymi w procesie rozwoju osobniczego.

Proces transkrypcji pojedynczej nici genu kodującego białko do RNA jest regulowany przez regiony kontrolne (regulatorowe), czyli wzmacniające i hamujące sekwencje niepodlegające transkrypcji, do których przyłączają się białka regulatorowe kodowane przez inne geny, przy czym gen może mieć wiele różnych sekwencji regulatorowych (za Futuyma 2008). Sekwencje regulatorowe oraz geny, które kodują cząsteczki RNA nieprzepisywane na białka, stanowią 98,5\% DNA (Pollard 2009).

Poza przekazem genetycznym praktyczne opanowanie konkretnego języka naturalnego wymaga również informacji zewnętrznej, rozumianej tu jako przekaz kulturowy (za Nowak, Nowakowski 2006; por. też Tomasello 2002), gdyż, jak zauważają Gorzelańczyk i Nowakowski (1999): „Pozagenetyczny przekaz informacji jest dla tempa ewolucji języka sprawą zasadniczą".

Niektórzy badacze zwracają uwagę na związki języka z pamięcią (Pinker 1991; Gorzelańczyk, Nowakowski 1999). W szczególności, jeśli język pozwala na uproszczenie zapisu engramów, to interesująca w tym kontekście zdaje się propozycja zawarta w (Kaczmarek 2000), według której „uczenie się może prowadzić do ekspresji genów syntetyzujących białka, których efektem działania jest zwiększenie siły połączeń synaptycznych między neuronami” (Sadowski 2001). Ponadto:

„(...) wykorzystanie biologicznego sprzężenia zwrotnego (biofeedback), czyli kontroli własnego stanu fizjologicznego oraz modyfikowania go według potrzeb jako metody wspomagającej proces uczenia się (...) potwierdza hipotezę o bliskich związkach uczenia się z pamięcią oraz językiem. Przypomnijmy, iż gest podkreśla emocjonalne podłoże sekwencji dźwięków (...) Również w przypadku wypowiedzi pozornie emocji pozbawionej, zachodzą pewne zmiany fizjologiczne sub rosa (zmienność rytmu serca - HRV, reakcja 
skórno-galwaniczna - GSR, zmiana napięcia autonomicznego układu nerwowego). Detekcja tego typu reakcji wykorzystywana jest już nie tylko w wykrywaczach kłamstw (...), ale też, jako się rzekło, może wspierać proces uczenia się." (Krysiak 2009)

Nazywając język przystosowaniem, musimy pamiętać, komu lub czemu to przystosowanie miałoby służyć. Inaczej mówiąc, pytamy o jednostkę doboru naturalnego. Zgodnie $\mathrm{z}$ koncepcją genocentryzmu (np. Dawkins 1996, 2003) to gen jest beneficjentem pojawiających się w ewolucji przystosowań. W najprostszym modelu, jeśli skojarzenie konkretnego dźwięku z konkretną sytuacją umożliwiało danemu osobnikowi przeżycie w chwili zagrożenia, to gen na tę cechę miał większe szanse na rozprzestrzenienie się w puli genowej niż jego alternatywne wersje (allomorfy)3. Dalej, osobnik, który wydawał i rozpoznawał więcej dźwięków, miał większe szanse w walce o byt. Wreszcie osobnik potrafiący lepiej wykorzystać system już istniejący, przekazywał swoje geny potomstwu (za Gorzelańczyk, Nowakowski 1999). W ten sposób geny na język przechodziły przez pokolenia, zwiększając liczbę swych kopii. Jest to jednak przykład uproszczony. W rzeczywistości oprócz wpływu na daną cechę $J$, należałoby jeszcze uwzględnić choćby genetyczny kontekst (otoczenie innych genów), proces regulacji ekspresji genu czy presję selekcyjną, od których wpływ ten również zależy. I tak, mimo iż ortologi FOXP2 (patrz niżej) u kręgowców wykazują się małą zmiennością, to niektóre gatunki nietoperzy zdają się być wyjątkiem (za Benítez-Burraco et al. 2008). Tłumaczyć to należy zapewne właśnie rozbieżnymi formami presji selekcyjnej, której poddane były te gatunki podczas ewolucji echolokacji. $Z$ drugiej jednak strony przykład ten pokazuje, że proces wczesnej, bo biologicznej ewolucji języka, był procesem kumulatywnym.

„Zdolności językowe sprzyjają przetrwaniu genów, które są za te zdolności odpowiedzialne, niezależnie od tego, czy geny te znajdują się w danym osobniku czy nie. Związane jest to $\mathrm{z}$ tym, że lepiej rozprzestrzeniają się geny, które umieją wywrzeć szerszy wpływ na środowisko.” (Gorzelańczyk, Nowakowski 1999)

O szerokim wpływie języka na środowisko nie trzeba nikogo przekonywać (por. Krebs, Dawkins 1984). Co więcej, spostrzeżenie to sugeruje, iż zasadne byłyby próby ujęcia języka w kategoriach „fenotypu rozszerzonego" (w rozumieniu Dawkins 2003).

3 Traktujemy tu gramatykę jako strukturę wyznaczającą projekcję linearnych struktur dźwiękowych na oś znaczeń (Pinker 1991). 


\section{Geny na język}

Najbardziej znanym przykładem genu na język jest znajdujący się na chromosomie 7 FOXP2 (ang. forkhead box P2). Jak dowiedli Lai et al. (2000) miejscowe uszkodzenie genu (7q31, w rejonie 5.6-cM, między D7S2459 i D7S643) spowodowało u 16 członków 3-pokoleniowej rodziny KE (badaniem objęto 30 osób) zaburzenia języka oraz, co istotne, zaburzenia praksji oralnej, dziedziczone autosomalnie dominująco (ibid.). Wytłumaczyć to można tym, iż gen $F O X P 2$ koduje czynnik transkrypcyjny FOXP2, który reguluje ekspresję setek genów, przez co ma wpływ na rozwój m.in. mózgowia, płuc, krtani, rozwój ruchowy (w tym właśnie praksję) oraz językowy. Zmiany na poziomie neuroanatomicznym opisują Belton et al. (2003) oraz Vargha-Khadem et al. (2005). W szczególności badanie wykonane metodą morfometrii wokselowej (ang. voxel-based morphometry, VBM) wykazało u chorych mniejszą gęstość istoty szarej w okolicach bieguna skroniowego (ang. temporal pole), obszaru Broki (44 i 45 obszar czołowy), jądra ogoniastego (ang. caudate nucleus), zakrętu przedśrodkowego (ang. precentral gyrus) i w móżdżku (ang. cerebellum) oraz zwiększoną gęstość w okolicy obszaru Wernickego (22 obszar skroniowy), zakrętu kątowego (39 obszar skroniowy) i skorupie (ang. putamen).

Jak informują Wasilewska et al. (2009) wielogenowy model dziedziczenia autyzmu (scil. zaburzeń z grupy Autystycznego Spektrum Zaburzeń) zakłada interakcję co najmniej 3-15 genów. FOXP2 (7q31) miałby być odpowiedzialny za zaburzenia mowy (patrz niżej). Obecnie wiadomo też, że mutacje FOXP2 mogą upośledzić zdolność amadyny zebrowatej (Taeniopygia guttata) do uczenia się nowych pieśni (Haesler et al. 2007) oraz oddziałują na ultradźwiękowe wokalizacje $\mathrm{u}$ myszy (Shu et al. 2005; Fujita et al. 2008). Okazało się też, że neandertalczycy (Homo neanderthalensis) mieli tę samą wersję genu co człowiek współczesny (Krause et al. 2009), chociaż mogła ona pełnić inne funkcje, jak sugerują Benítez-Burraco et al. (2008).

Czynnik transkrypcyjny FOXP2 reguluje ekspresję CNTNAP2, jednego $\mathrm{z}$ największych genów w ludzkim genomie (zajmuje prawie 1,5\% powierzchni chromosomu 7), który koduje białko CNTNAP2 (ang. Contactin-associated protein-like 2). Najnowsze badania etiologii zaburzeń z grupy Autystycznego Spektrum Zaburzeń wskazują na rolę tego właśnie genu w rozwoju wspomnianych zaburzeń (Alarcón et al. 2008; Arking et al. 2008; Vernes et al. 2008). Ponadto łączy się (Vernes et al. 2008) polimorfizm pojedynczego nukleotydu w CNTNAP2 z występowaniem zespołu SLI (ang. specific language impairment specyficzne zaburzenie rozwoju językowego).

Próby zidentyfikowania fragmentów DNA charakterystycznych tylko dla człowieka (Homo sapiens) (Pollard 2009) koncentrują się na poszukiwaniu sekwencji DNA, które uległy największym zmianom od czasu, gdy ewolucyjne drogi człowieka i szympansa oddzieliły się od siebie (czyli w przeciągu ostatnich $6 \mathrm{mln}$ lat). Oprócz wspomnianej sekwencji 
FOXP2 wymienia się też m.in. ASPM (MCPH5), którego zmienność wskazuje na działanie selekcji pozytywnej (Evans et al. 2005). Gen ten, wraz z MCPH1 (Microcephalin), CDK5RAP2 (MCPH3) i CENPJ (MCPH6) biorą udział w kontrolowaniu rozmiaru mózgu, a ich mutacje odpowiadać mogą za mikrocefalię (małogłowie). W swej analizie Dediu i Ladd (2007) wskazują, iż istnieje powiązanie międzypopulacyjnych różnic w ASPM oraz MCPH1 z międzyjęzykową dystrybucją tonów. W konsekwencji językami tonalnymi miałyby posługiwać się populacje o niskiej frekwencji pochodnych haplogrup $A S P M-D$ oraz $M C P H-D$, a genetyczna i językowa różnorodność są skorelowane nie tylko na osobniczym, ale też populacyjnym poziomie (Ladd et al. 2008)4.

\section{Perspektywy dalszych badań}

Prezentowane tu podejście stwarza nowe możliwości spojrzenia na język wraz ze wszystkimi jego (języka) właściwościami, widzianymi z perspektywy synchronicznej i diachronicznej. Samo wykorzystanie ustaleń genetyki ewolucyjnej (czy szerzej - biologii ewolucyjnej) na gruncie językoznawstwa zdaje się przedsięwzięciem tyleż trudnym, co ważkim. Zdaniem niżej podpisanego na szczególną uwagę zasługują takie wyzwania jak: aplikacja teorii gier, a zwłaszcza koncepcji strategii ewolucyjnie stabilnej (ang. evolutionary stable strategy - ESS) (np. Maynard Smith, Price 1973) w odniesieniu do komunikacji językowej, potraktowanie wczesnej ewolucji języka jako „wyścigu zbrojen”” (tzw. hipoteza Czerwonej Królowej), wreszcie spojrzenie na genetyczne podstawy języka z punktu widzenia genocentryzmu oraz potraktowanie języka jako fenotypu rozszerzonego, co tutaj tylko zasygnalizowaliśmy. Tak czy inaczej:

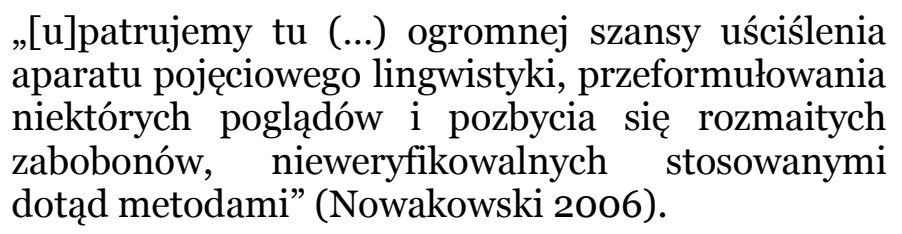

Pozostaje mieć nadzieję, iż nowe odkrycia nie okażą się na tyle druzgocące, by trzeba było zaprzeczyć stojącym za nimi faktom.

4 Chociaż nie możemy $\mathrm{w}$ tym przypadku mówić explicite o językowej cesze przystosowawczej. 


\section{Bibliografia}

Alarcón M., Abrahams B.S., Stone J.L., Duvall J.A., Perederiy J.V., Bomar J.M., Sebat J., Wigler M., Martin C.L., Ledbetter D.H., Nelson S.F., Cantor R.M., Geschwind D.H. (2008) Linkage, association, and gene-expression analyses identify CNTNAP2 as an autism-susceptibility gene. The American Journal of Human Genetics 82: 150-9.

Arking D.E., Cutler D.J., Brune C.W., Teslovich T.M., West K., Ikeda M., Rea A., Guy M., Lin S., Cook E.H., Chakravarti A. (2008) A Common Genetic Variant in the Neurexin Superfamily Member CNTNAP2 Increases Familial Risk of Autism. The American Journal of Human Genetics 82: 160-4.

Belton E., Salmond C.H., Watkins K.E., Vargha-Khadem F., Gadian D.G. (2003) Bilateral brain abnormalities associated with dominantly inherited verbal and orofacial dyspraxia. Human Brain Mapping 18: 194-200.

Benítez-Burraco A., Longa V.M., Lorenzo G., Uriagereka J. (2008) Also sprach Neanderthalis... Or Did She? Biolinguistics 2(2): 225-32.

Dawkins R. (1996) Samolubny gen. Warszawa: Prószyński i S-ka.

Dawkins R. (2003) Fenotyp rozszerzony. Warszawa: Prószyński i S-ka.

Dediu D., Ladd D.R. (2007) Linguistic tone is related to the population frequency of the adaptive haplogroups of two brain size genes, ASPM and Microcephalin. Proceedings of the National Academy of Sciences of the United States of America 104: 1944-9.

Evans P.D., Gilbert S.L., Mekel-Bobrov N., Vallender E.J., Anderson J.R.,VaezAzizi L.M., Tishkoff S.A., Hudson R.R., Lahn B.T. (2005) Microcephalin, a Gene Regulating Brain Size, Continues to Evolve Adaptively in Humans. Science 309: 1717-20.

Fujita E., Tanabe Y., Shiota A., Ueda M., Suwa K., Momoi M.Y., Momoi T. (2008) Ultrasonic vocalization impairment of Foxp2 (R552H) knockin mice related to speech-language disorder and abnormality of Purkinje cells. Proceedings of the National Academy of Sciences of the United States of America 105: 311722.

Futuyma D.J. (2008) Ewolucja. Warszawa: Wydawnictwo Uniwersytetu Warszawskiego.

Gorzelańczyk E.J., Nowakowski P. (1999) Pamięć, świadomość i biologiczne podłoże pochodzenia języka. Investigationes Linguisticae 7: 161-72.

Haesler S., Rochefort C., Georgi B., Licznerski P., Osten P., Scharff C. (2007). Incomplete and Inaccurate Vocal Imitation after Knockdown of FoxP2 in Songbird Basal Ganglia Nucleus Area X. PLoS Biology 5(12), e321. DOI: 10.1371/journal.pbio.0050321

Kaczmarek L. (2000) Gene expression in learning processes. Acta neurobiologiae experimentalis 60: 419-24.

Krause J., Lalueza-Fox Ch., Orlando L., Enard W., Green R.E., Burbano H.A., Hublin J.J., Hänni C., Fortea J., de la Rasilla M., Bertranpetit J., Rosas A., Pääbo S. (2007) The derived FOXP2 variant of modern humans was shared with Neandertals. Current Biology 17, pp. 1908-12.

Krebs J.R., Davies N.B. (red) (1984) Behavioural Ecology: an evolutionary approach. Sunderland, MA: Sinauer Associates.

Krebs J.R, Dawkins R. (1984) Animal signals: mind-reading and manipulation. W: Krebs J.R., Davies N.B. (red): 380-402.

Krysiak A.P. (2009) Perspektywa bio- i neurolingwistyczna jako nowa determinanta w badaniach nad językiem (w druku). 
Ladd D.R., Dediu D., Kinsella A.R. (2008) Languages and Genes: Reflections on Biolinguistics and the Nature-Nurture Question. Biolinguistics 2(1): 114-26.

Lai C.S.L., Fisher S.E., Hurst J.A., Levy E.R., Hodgson S, Fox M., Jeremiah S, Povey S., Jamison D.C., Green E.D., Vargha-Khadem F., Monaco A.P. (2000) The SPCH1 Region on Human 7q31: Genomic Characterization of the Critical Interval and Localization of Translocations Associated with Speech and Language Disorder. The American Journal of Human Genetics 67:357-68

Maynard Smith J., Price G.R. (1973) The Logic of Animal Conflict. Nature 246: $15-8$.

Nowak P., Nowakowski P. (red.) (2006) Język, Komunikacja, Informacja. Tom I. Poznań: Sorus.

Nowak P., Nowakowski P. (2006) Człowiek a potrzeba informacji. Kilka refleksji na marginesie założeń teorii społeczeństwa informacji. W: Nowak P., Nowakowski P. (red.): 157-66.

Nowakowski P. (2006) Emocjonalne podłoże wypowiedzi językowych. Zarys problematyki z perspektywy biolingwistyki. W: Nowak P., Nowakowski P. (red.):143-55.

Pinker S. (1991) Rules of Language. Science 253: 530-5.

Pinker S., Bloom P. (1990) Natural language and natural selection. The Behavioral and brain sciences 13(4): 707-84.

Pollard K.S. (2009) Człowieczeństwo zapisane w genach. Świat nauki 6(214): 3843.

Sadowski B. (2001) Biologiczne mechanizmy zachowania się ludzi i zwierząt. Warszawa: Wydawnictwo Naukowe PWN.

Shu W., Cho J.Y., Jiang Y., Zhang M., Weisz D., Elder G.A., Schmeidler J., De Gasperi R., Sosa M.A., Rabidou D., Santucci A.C., Perl D., Morrisey E., Buxbaum J.D. (2005) Altered ultrasonic vocalization in mice with a disruption in Foxp2 gene. Proceedings of the National Academy of Sciences of the United States of America 102: 9643-8.

Tomasello M. (2002) Kulturowe źródta ludzkiego poznawania. Warszawa: Państwowy Instytut Wydawniczy.

Vargha-Khadem F., Gadian D.G., Copp A., Mishkin M. (2005) FOXP2 and the neuroanatomy of speech and language. Nature reviews. Neuroscience 6(2):131-8.

Vernes S.C., Newbury D.F., Abrahams B.S., Winchester L., Nicod J., Groszer M., Alarcón M., Oliver P.L., Davies K.E., Geschwind D.H., Monaco A.P., Fisher S.E. (2008) A functional genetic link between distinct developmental language disorders. The New England journal of medicine 359: 2337-45.

Wasilewska J., Jarocka-Cyrta E., Kaczmarski M. (2009) Patogeneza zaburzeń przewodu pokarmowego u dzieci z autyzmem. Polski Merkuriusz Lekarski XXVII, 157, 40; http://pml.strefa.pl/ePUBLI/157/o9.pdf (22 X 2009) 